\title{
Comparing Irrigation Systems and Strategies for Table Grapes in the Weathered Granite-gneiss Soils of the Lower Orange River Region
}

\author{
P.A. Myburgh \\ ARC Infruitec-Nietvoorbij ${ }^{1}$, Private Bag X5026, 7599, Stellenbosch, South Africa \\ Submitted for publication: February 2012 \\ Accepted for publication: August 2012
}

Key words: Thompson Seedless, drip, micro-sprinklers, soil water, evapotranspiration, cane mass, yield, grape quality

\begin{abstract}
Drip and micro-sprinkler irrigation systems were compared in a Thompson Seedless/Ramsey table grape vineyard in a weathered granite-gneiss soil in the Lower Orange River region. For each system, two different irrigation strategies were investigated. Drip irrigation frequencies of two days or longer, induced more water constraints in grapevines compared to micro-sprinkler irrigation applied at the same frequencies in the 1996/97 and 1997/98 seasons. Higher water constraints imposed by drip irrigation had negative effects on vegetative growth, berry size and grape quality compared to micro-sprinkler irrigation. However, responses of drip irrigated grapevines were comparable to micro-sprinkler irrigated grapevines when drip irrigations were applied daily in the 1998/99 and 1999/2000 seasons. Daily, early morning drip irrigation increased evapotranspiration (ET) by $6 \%$ compared to drip during the warmest part of the day. Drip irrigation suppressed weed growth considerably compared to micro-sprinklers. Daily ET of the drip irrigated grapevines was substantially lower compared to micro-sprinkler irrigated grapevines that received either two or three irrigations per week. In the case of micro-sprinklers, the higher frequency increased ET by $8 \%$ compared to the lower irrigation frequency. Since micro-sprinkler irrigation invariably produced higher yields than drip irrigation during the four seasons, it should be the preferred system for irrigation of table grapes under the given atmospheric and soil conditions. If water resources are limited, or if high water cost reduces table grape profitability, drip irrigation merits consideration as an alternative. However, daily drip irrigation will be required during the growing season to maintain acceptable yields and grape quality.
\end{abstract}

\section{INTRODUCTION}

Production of export table grapes is a major agricultural industry in the Lower Orange River region of the Northern Cape Province of South Africa. Table grape production in this region depends on irrigation. Initially, Thompson Seedless (also known as Sultanina or Sultana) vineyards were planted in the alluvial soils along the river. As a result, previous studies focused on determining irrigation requirements for vineyards in these soils (Myburgh, 2003a, 2007a). As the industry expanded over time, vineyards were established in the soils away from the river. Irrigation requirements were also determined for these vineyards (Myburgh, 2003b). Vineyards were also established in lithic soils derived from the granite-gneiss that commonly occurs in the Northern Cape Province. In their natural state, these lithic soils have low agricultural potential, but when the rooting depth is increased by deep ripping they are suitable for sustainable export table grape production if under irrigation (Fey, 2010).

Since water restrictions are imposed during the summerdroughts in the catchments of the Orange River, growers are encouraged to use efficient irrigation systems. Water can be applied more efficiently by means of drip irrigation systems compared to systems that wet the total surface (Ley, 1994). It has been shown that irrigation requirements for drip irrigated table grapes are substantially lower compared to microsprinkler irrigated grapevines (Saayman \& Lambrechts, 1995). It was also found that furrow irrigation improves irrigation water productivity (IWP), i.e. mass of grapes produced per unit volume of irrigation water (Sadras, 2009), compared to full surface flood irrigation in the alluvial soils of the Lower Orange River region (Myburgh, 2003a). Due to the uneven topography of the land away from the river,

\footnotetext{
${ }^{1}$ The Fruit, Vine and Wine Institute of the Agricultural Research Council

*Corresponding author: E-mail: myburghp@arc.agric.za

Acknowledgements: The ARC for infrastructure and other resources, Deciduous Fruit Producers 'Trust and Dried Fruit Technical Services for partial funding, Spilhaus and Netafim SA for sponsoring irrigation equipment, Messrs. R.K. Oosthuizen and sons for permission to work in their vineyard and the Soil and Water Science staff at ARC Infruitec-Nietvoorbij for technical support.
} 
micro-sprinkler or drip irrigation is preferred for irrigation of vineyards in the lithic soils. Frequent applications of water and nutrients are required for drip irrigated crops in order to maintain root development, soil water availability and aeration, as well as to prevent water and minerals percolating to deeper layers (Bravdo, 2000, 2008). Due to the partial soil wetting, drip irrigation can induce more water constraints in grapevines than full surface irrigation. A previous study showed that drip irrigated Barlinka table grapes in sandy soils in the Hex River valley consistently experienced more water constraints from flowering until harvest than microsprinkler irrigated grapevines (Myburgh, 1996). In that particular study, both irrigation systems were used to irrigate grapevines when $40 \%$ of the plant available water (PAW) was depleted. In the case of drip irrigation, the smaller wetted soil volume also increases the risk of excessive water constraints, and requires more management inputs than micro-sprinklers (Saayman \& Lambrechts, 1995). However, grapevines in fertile soils potentially produce equally high yields under almost any irrigation system if irrigation scheduling is properly managed (Van Zyl, 1984; Myburgh, 2007b).

Many factors, notably climate, soil, water and vineyard management can influence the vegetative growth and yield of export table grapes (Pérez-Harvey, 2008). Vegetative growth, yield and table grape quality depend indirectly on grapevine water status (Van Rooyen et al., 1980; Fourie, 1989; Myburgh, 1996; El-Ansary et al., 2005; Myburgh \& Howell, 2006a, 2006b, 2007a). Consequently, irrigation is an important management practice to ensure economically viable production of export grapes. In South Africa, water is already a scarce resource, and is becoming increasingly expensive. Furthermore, if climate change causes drier summers in the catchments of the Orange River it could reduce flow rates, and impede replenishment of dams that store water for irrigation purposes. Therefore, irrigation strategies need to be developed or refined to obtain optimum grape quality without compromising yield or water use efficiency.

The objective of this study was to determine the irrigation requirements for drip and micro-sprinkler irrigation of table grapes grown in a lithic soil in the Lower Orange River region.

\section{MATERIALS AND METHODS \\ Experiment layout}

This field trial commenced during 1996 in an eight-yearold drip irrigated Thompson Seedless/Ramsey vineyard in the Augrabies region of the Lower Orange River region in South Africa. The region has a summer rainfall climate with hot summers and dry winters with low night temperatures (Table 1). Based on the growing degree days (GDD) from September until March (Winkler, 1962), the specific locality is in a class $\mathrm{V}$ climatic region for viticulture (Le Roux, 1974). The soil, which was derived from weathered granitegneiss, belongs to the orthic variant within the lithic group of soils (Fey, 2010). Before the vineyard was planted, the soil was deep-ripped using a crawler tractor to extend the potential rooting depth to at least $800 \mathrm{~mm}$. Representative soil samples were collected from the $0-300 \mathrm{~mm}$ and $300-$
$600 \mathrm{~mm}$ depth increments. The soil chemical status and particle size distribution were determined by a commercial laboratory (Bemlab, Strand). Grapevines were spaced 3.65 $\mathrm{m} \times 2 \mathrm{~m}$ and trained onto a Gable trellis (Avenant, 1991). Grapevines were cane pruned, allowing 12 to 18 nodes per cane. Pruning canes were mechanically chopped, and left on the soil surface. Herbicides were applied full surface before bud break, and after fruit set if necessary, to control weeds. Despite this, weeds still emerged from mid-summer onwards. To quantify the effect of irrigation system and frequency on the summer weed growth, the dry matter production (DMP) was determined each season in April. On each plot, all weeds in the $7.3 \mathrm{~m}^{2}$ area between four experiment grapevines were removed using a pair of sheep shears. Weed samples were placed in paper bags and dried in a fan oven at $60^{\circ} \mathrm{C}$ until constant mass was attained. Following this, the samples were weighed and the dry mass $(\mathrm{g})$ converted to ton per hectare.

The irrigation treatments were applied over four seasons, i.e. from September 1996 until July 2000. Grapevines were either irrigated by means of drippers (T1 \& T2), or microsprinklers (T3 \& T4). Due to the coarse nature of the soil, the drippers (RAM 3.5 L/h, Netafim) were spaced 600 $\mathrm{mm}$ apart in the lines. The micro-sprinklers (Eintal $32 \mathrm{~L} / \mathrm{h}$, Spilhaus) were spaced $2 \mathrm{~m}$ apart in the grapevine rows to obtain total surface wetting. For each irrigation system, grapevines were either irrigated three times per week (T1 \& T3), or weekly (T2 \& T4) from bud break (late August) until leaf fall (May) in the 1996/97 season. In the 1997/98 season, drip irrigations were either applied three times per week (T1) or twice a week (T2) from bud break until leaf fall. In the 1998/99 and 1999/2000 seasons, the T1 grapevines were drip irrigated daily during the early morning, i.e. from 06:00, whereas the T2 grapevines were irrigated daily over the warmest part of the day, i.e. between 10:00 and 15:00. In the case of treatment $\mathrm{T} 2$, dripper lines with a lower flow rate (RAM $2.3 \mathrm{~L} / \mathrm{h}$, Netafim) were installed to increase the time that the T2 grapevines were exposed to irrigation, but still receive the same volume of water as the T1 grapevines. From the 1997/98 until the 1999/2000 season, the microsprinkler irrigations were either applied three times per week (T3) or twice a week (T4) from bud break until leaf fall. In the 1996/97 and 1997/98 seasons, grapevines were irrigated only once per week during the dry winters, irrespective of the irrigation system. In the 1998/99 and 1999/2000 seasons, the drip irrigated grapevines were irrigated twice a week during winter, whereas the micro-sprinkler irrigated grapevines received one irrigation per week. The existing drip irrigation system was adapted so that each treatment could be irrigated individually. Electronic timers (Miracle 6 , Netafim) were used to control the irrigations of the four treatments. The $233.6 \mathrm{~m}^{2}$ experiment plots consisted of two rows of six experiment grapevines with a border grapevine at each end, and a border row on each side, to minimise overlapping treatment effects. Treatments were replicated four times in a fully randomised design. Fertilizers were applied at the end of September and in mid-April through the drippers, as well as micro-sprinklers (Table 2). At both stages, fertilizers were split into two equal increments, which were applied one week apart. 
TABLE 1

Long term mean monthly maximum $\left(\mathrm{T}_{\mathrm{x}}\right)$ and minimum $\left(\mathrm{T}_{\mathrm{n}}\right)$ air temperature, maximum $\left(\mathrm{RH}_{\mathrm{x}}\right)$ and minimum $\left(\mathrm{RH}_{\mathrm{n}}\right)$ relative humidity, wind speed and rainfall for the Augrabies-Witklip weather station. Data are means of fourteen years and were obtained from the ARC Institute for Soil, Climate and Water in Pretoria.

\begin{tabular}{|c|c|c|c|c|c|c|}
\hline Month & $\mathbf{T}_{\mathrm{x}}\left({ }^{\circ} \mathrm{C}\right)$ & $\mathbf{T}_{\mathrm{n}}\left({ }^{\circ} \mathrm{C}\right)$ & $\mathrm{RH}_{\mathrm{x}}(\%)$ & $R H_{n}(\%)$ & Wind speed $(\mathrm{m} / \mathrm{s})$ & Rainfall (mm) \\
\hline August & 25.0 & 6.7 & 68.8 & 21.9 & 1.8 & 0.7 \\
\hline September & 28.2 & 9.7 & 71.7 & 17.9 & 1.8 & 3.9 \\
\hline October & 31.3 & 14.1 & 67.4 & 18.4 & 1.9 & 12.8 \\
\hline November & 33.1 & 16.2 & 66.2 & 15.7 & 2.1 & 16.6 \\
\hline December & 35.8 & 18.4 & 68.8 & 14.9 & 3.4 & 18.1 \\
\hline January & 36.7 & 20.1 & 67.3 & 18.0 & 2.0 & 16.4 \\
\hline February & 36.6 & 20.4 & 72.4 & 22.2 & 1.7 & 15.4 \\
\hline March & 34.1 & 18.3 & 77.6 & 26.3 & 1.8 & 21.1 \\
\hline April & 29.5 & 14.0 & 80.4 & 26.3 & 1.7 & 15.4 \\
\hline May & 25.3 & 8.2 & 83.8 & 30.2 & 1.4 & 10.9 \\
\hline June & 21.8 & 4.5 & 82.0 & 29.6 & 1.5 & 3.3 \\
\hline July & 23.1 & 5.2 & 76.8 & 25.2 & 1.7 & 1.0 \\
\hline
\end{tabular}

TABLE 2

Timing and amounts of nitrogen $(\mathrm{N})$, phosphorus $(\mathrm{P})$ and potassium $(\mathrm{K})$ applied annually to a Thompson Seedless table grape vineyard near Augrabies in the Lower Orange River region.

\begin{tabular}{lcccr}
\hline \multirow{2}{*}{ Time } & Fertilizer mix & \multicolumn{3}{c}{ Element applied (kg/ha) } \\
\cline { 3 - 5 } & & $\mathbf{N}$ & $\mathbf{P}$ & \multicolumn{1}{c}{ K } \\
\hline End of September & $10: 1: 2(24)$ & 34.1 & 3.4 & 10.2 \\
Mid-April & $3: 1: 2(20)$ & 30.5 & 20.3 \\
\hline
\end{tabular}

\section{Soil water status}

Mercury manometer tensiometers were used to measure treatment effects on soil water matric potential $\left(\Psi_{\mathrm{m}}\right)$ at $300 \mathrm{~mm}$ and $600 \mathrm{~mm}$ depths. Irrigation volumes were measured using water meters. Irrigation volumes and $\Psi_{\mathrm{m}}$ were monitored in two replications of each of the four irrigation treatments. Soil bulk densities $\left(\rho_{\mathrm{b}}\right)$ of $2.8 \times 10^{-4}$ $\mathrm{m}^{3}$ undisturbed soil cores were determined in each of the top- and subsoil layers, respectively. Four soil pits were excavated at representative locations within the vineyard to collect the $\rho_{\mathrm{b}}$ samples. The soil pits revealed that most of the roots occurred to a depth of approximately $800 \mathrm{~mm}$, and that only a limited number of roots extended deeper. Gravimetric soil water content was measured as the soil dried out between irrigations in the first season. The $\rho_{\mathrm{b}}$ was used to convert gravimetric soil water content to volumetric soil water content $\left(\mathrm{SWC}_{\mathrm{v}}\right)$. Soil water characteristic curves were obtained from the relationship between $\mathrm{SWC}_{\mathrm{V}}$ and $\Psi_{\mathrm{m}}$ for the 0-500 $\mathrm{mm}$ and 500-800 $\mathrm{mm}$ depth increments, respectively. Readily available water (RAW) in each layer was calculated as the $\mathrm{SWC}_{\mathrm{V}}$ difference between $\Psi_{\mathrm{m}}$ values of $-0.003 \mathrm{MPa}$ and -0.1 MPa. Previous studies have shown that in situ determined field capacity (FC) in sandy soil was at $c a$. -0.003 MPa (Myburgh, 1996; Conradie \& Myburgh, 2000). The RAW in the different soil layers were summed to obtain a total, i.e. $\mathrm{mm}$ water per $800 \mathrm{~mm}$ root depth.

\section{Grapevine response}

Trenches that were excavated across the grapevine rows for installation of the sub mains of the adapted irrigation system confirmed that the root depth was approximately $800 \mathrm{~mm}$. Although roots were concentrated in a $c a .900 \mathrm{~mm}$ wide band along the grapevine rows, some roots extended to the middle of the work rows. Water could therefore be absorbed from the work row where the micro-sprinklers wetted the total surface. Grapevine water status was quantified close to harvest by measuring midday leaf water potential $\left(\Psi_{L}\right)$ using the pressure chamber technique (Scholander et al., 1965) according to the protocol described by Myburgh (2010). In the 1998/99 and 1999/2000 seasons, predawn leaf water potential $\left(\Psi_{\mathrm{PD}}\right)$ was also measured at 04:00. Water potential was measured in a mature, unscathed leaf on one primary shoot per plot. During daytime, $\Psi_{L}$ was measured in leaves that were fully exposed to the sun. Fresh berry mass was determined in all the plots at harvest. Berry samples were obtained by picking ten berries along the longitudinal axis from each of five bunches per plot. Berries were removed by cutting through the pedicel as close as possible to the berry using a small pair of scissors. All bunches in each plot were picked and counted. The grapes were weighed to obtain the total mass per plot. Mean yield per grapevine was calculated and converted to ton per hectare. Bunch mass was determined by dividing total grape mass per plot by the number of bunches per plot. The objective was to harvest grapes when the sugar content reached a target of $16^{\circ} \mathrm{B}$ but, due to logistical constraints, this was not always possible. Total soluble solids (TSS), $\mathrm{pH}$ and total titratable acidity (TTA) in the juice were determined according to the standard 
procedures of the winery at ARC Infruitec-Nietvoorbij. Vegetative growth was quantified by measuring cane mass of the experiment grapevines in each plot at pruning in July using a hanging balance. In the 1997/98 season, grapevine nutrient status was determined at flowering and véraison. In the 1998/99 season, grapevine nutrient status was also assessed just after bud break and when berries reached pea size. For this purpose, samples consisting of 30 mature leaf blades were picked from a main shoot opposite a bunch on each plot. Leaf blades were analysed for nitrogen $(\mathrm{N})$, phosphorus $(\mathrm{P})$, potassium $(\mathrm{K})$, calcium $(\mathrm{Ca})$ and magnesium $(\mathrm{Mg})$ according to the standard procedures of the soil laboratory at ARC Infruitec-Nietvoorbij. Grapevine nutrient status was evaluated according to norms based on leaf blade macro-element content at flowering, i.e. 1.6\% to $2.7 \% \mathrm{~N}, 0.14 \%$ to $0.55 \% \mathrm{P}, 0.65 \%$ to $1.3 \% \mathrm{~K}, 1.2 \%$ to $2.2 \%$ $\mathrm{Ca}$ and $0.16 \%$ to $0.55 \% \mathrm{Mg}$ (Conradie, 1994 ).

All bunches on each experiment plot were evaluated according to three quality classes, i.e. for export markets, for local markets and for juice production. Following this, a sample of the export quality grapes from each plot was packed into a $9 \mathrm{~kg}$ carton according to industry standards. These grapes were stored for four weeks at $4{ }^{\circ} \mathrm{C}$ followed by one week at $10^{\circ} \mathrm{C}$. Grapes were then evaluated for loose berries, $\mathrm{SO}_{2}$ damage and the occurrence of berry crack on a mass basis following the cold storage period during the first three seasons. A panel of at least fifteen members evaluated the grapes sensorially during all seasons for colour, firmness, taste and overall impression according to an ordinal scale, i.e. $1=$ poor, 2 = fairly poor, $3=$ average, $4=$ fairly good and $5=$ good.

\section{Evapotranspiration and crop coefficients}

The universal water balance equation was used to calculate evapotranspiration on a weekly basis as follows:

$\mathrm{ET}+\mathrm{SWC}_{\mathrm{b}}+\mathrm{I}+\mathrm{P}-\mathrm{SWC}_{\mathrm{e}}-\mathrm{D}-\mathrm{R}=0$

where ET is cumulative evapotranspiration per week, $\mathrm{SWC}_{\mathrm{b}}$ and $\mathrm{SWC}_{\mathrm{e}}$ are volumetric soil water contents at the beginning and end of the period, respectively, I is irrigation applied, $\mathrm{P}$ is precipitation, $\mathrm{D}$ is drainage and $\mathrm{R}$ is run-off losses. All units were in millimeters. No water run-off from the surface was observed, probably due to the coarse nature of the soil. Since $\mathrm{D}$ could not be measured, it was estimated as the difference between the water deficit at the beginning of a period (FC - $\mathrm{SWC}_{\mathrm{b}}$ ) and the irrigation applied, i.e. if the irrigation exceeded $\mathrm{FC}-\mathrm{SWC}_{\mathrm{b}}$. Irrigation application efficiencies of the drip and micro-sprinkler systems were assumed to be $90 \%$ and $80 \%$, respectively (Ley, 1994). In the case of drip irrigation, the soil water balance (Eq. 1) was calculated for the wetted volume, which was estimated as $25 \%$ of the total volume according to the observed root distribution. To allow comparison between irrigation systems, ET of the drip irrigated grapevines was expressed on the total surface. Crop coefficients $\left(\mathrm{k}_{\mathrm{c}}\right)$ were calculated as follows:

$\mathrm{k}_{\mathrm{c}}=\mathrm{ET} / \mathrm{ET}_{\mathrm{o}}$

where $\mathrm{ET}_{\mathrm{o}}$ is the modified Penman-Monteith reference crop evapotranspiration (Allen et al., 1998). For the duration of the trial, air temperature, relative humidity, wind speed at 2 $\mathrm{m}$ height, insolation and precipitation were recorded hourly using an automatic weather station (MC Systems, Cape Town) located $150 \mathrm{~m}$ from the vineyard. Hourly ET was calculated according to Allen et al. (1998) and summed to obtain daily $\mathrm{ET}_{\mathrm{o}}$.

\section{Statistical analysis}

Frequencies observed in the five sensorial quality classes were analysed using a general linear model (GLM) technique with a logistic link function. Maximum likelihood estimators (Xbetas) were calculated on an underlying scale (McCullagh \& Nelder, 1989). Two-way analyses of variance were performed on the mean degree of grape colour, firmness, taste and overall impression using SAS version 8.2 (SAS, 1999). The Shapiro-Wilk test was performed to test for non-normality (Shapiro \& Wilk, 1965). Student's $\mathrm{t}$ least significant difference (LSD) values were calculated to facilitate comparison between treatment means. Means that differed at $\mathrm{p} \leq 0.05$ were considered to be significantly different. Since there was no evidence against normality, transformation was not necessary.

\section{RESULTS AND DISCUSSION \\ Soil conditions}

The $\mathrm{pH}_{(\mathrm{KCl})}$ of the sandy soil (clay $<3 \%$ ) was 6.7. There were no signs of salinity or sodicity that could have had negative effects on grapevine growth or yield (data not shown). The exchangeable Ca content was $c a .20 \mathrm{cmol}^{(+)} / \mathrm{kg}$, which constituted $80 \%$ of the base saturation. High Ca with relatively low $\mathrm{Mg}, \mathrm{K}$ and $\mathrm{Na}$ are common in the soils away from the river (Volschenk et al., 2005). Mean $\rho_{\mathrm{b}}$ was $1678 \pm 75$ $\mathrm{kg} / \mathrm{m}^{3}$ and $1672 \pm 96 \mathrm{~kg} / \mathrm{m}^{3}$ in the topsoil (0 to $400 \mathrm{~mm}$ ) and subsoil (400 mm to $800 \mathrm{~mm}$ ) layers, respectively. The $\rho_{\mathrm{b}}$ was comparable to $1600 \mathrm{~kg} / \mathrm{m}^{3}$ reported for a fine sandy soil near Upington in the Lower Orange River region (Myburgh, 2003b), but higher than $1480 \mathrm{~kg} / \mathrm{m}^{3}$ for a coarse sandy soil in the Hex River valley (Myburgh \& Howell, 2007b). The soil water characteristic curves were similar for the different layers (Fig. 1), which indicated that almost no differentiation occurred within the profile of this relatively young soil (Fey, 2010). The RAW retained between $-0.003 \mathrm{MPa}$ and $-0.1 \mathrm{MPa}$ amounted to $124 \mathrm{~mm}$ over the $800 \mathrm{~mm}$ rooting depth. The unexpectedly high RAW for the sandy was probably due to the $c a .40 \%$ fine sand content. Previous studies showed that a sandy soil in the Hex River valley retained $112 \mathrm{~mm}$ water between $-0.003 \mathrm{MPa}$ and $-0.1 \mathrm{MPa}$ over a $1.2 \mathrm{~m}$ root depth (Myburgh \& Howell, 2007b), whereas a sandy soil in Lower Olifants River region retained $109 \mathrm{~mm} / \mathrm{m}$ RAW between $-0.005 \mathrm{MPa}$ and -0.1 MPa (Myburgh, 2011). The foregoing confirmed that sandy soils could retain high levels of RAW. The soil water characteristic curves revealed that most of the RAW occurred at $\Psi_{\mathrm{m}}$ values higher than $-0.02 \mathrm{MPa}$ (Fig. 1). Similar trends were reported for a sandy soil in the Lower Olifants River region (Conradie \& Myburgh, 2000) and a coarse sandy soil in the Hex River valley in the Western Cape (Myburgh \& Howell, 2007b). Previous results showed that $\Psi_{\mathrm{m}}$ values below $c a$. $-0.02 \mathrm{MPa}$ had negative effects on grapevine growth (Saayman \& Lambrechts, 1995). 


\section{Grapevine response}

1996/97 Season

Due to breakdowns in both irrigation systems, the soil frequently dried to below $-0.02 \mathrm{MPa}$ during the 1996/97 season (data not shown). According to the $\Psi_{\mathrm{L}}$ classification proposed by Greenspan (2005), the dry soil conditions induced moderate midday water constraints in grapevines of most treatments, but strong constraints in the weekly drip irrigated grapevines (Table 3). Water constraints in the micro-sprinkler irrigated grapevines tended to be less severe than in the drip irrigated grapevines. This suggested that grapevines could absorb water throughout work rows where micro-sprinklers wetted the total surface. Malfunctioning of the irrigation system had a less pronounced effect on berry mass of the micro-sprinkler irrigated grapevines than on their drip irrigated counterparts (Table 3). The smaller berries resulted in lower bunch masses and yields. The dry soil conditions, and the resulting water constraints, tended to have a more negative effect on vegetative growth of drip irrigated grapevines compared to micro-sprinkler irrigated grapevines (Table 3). The different irrigation systems had no effect on juice TSS, TTA or $\mathrm{pH}$ at harvest on 24 December 1996 (Table 3). Due to smaller berries and bunches, the export quality of the drip irrigated grapevines was

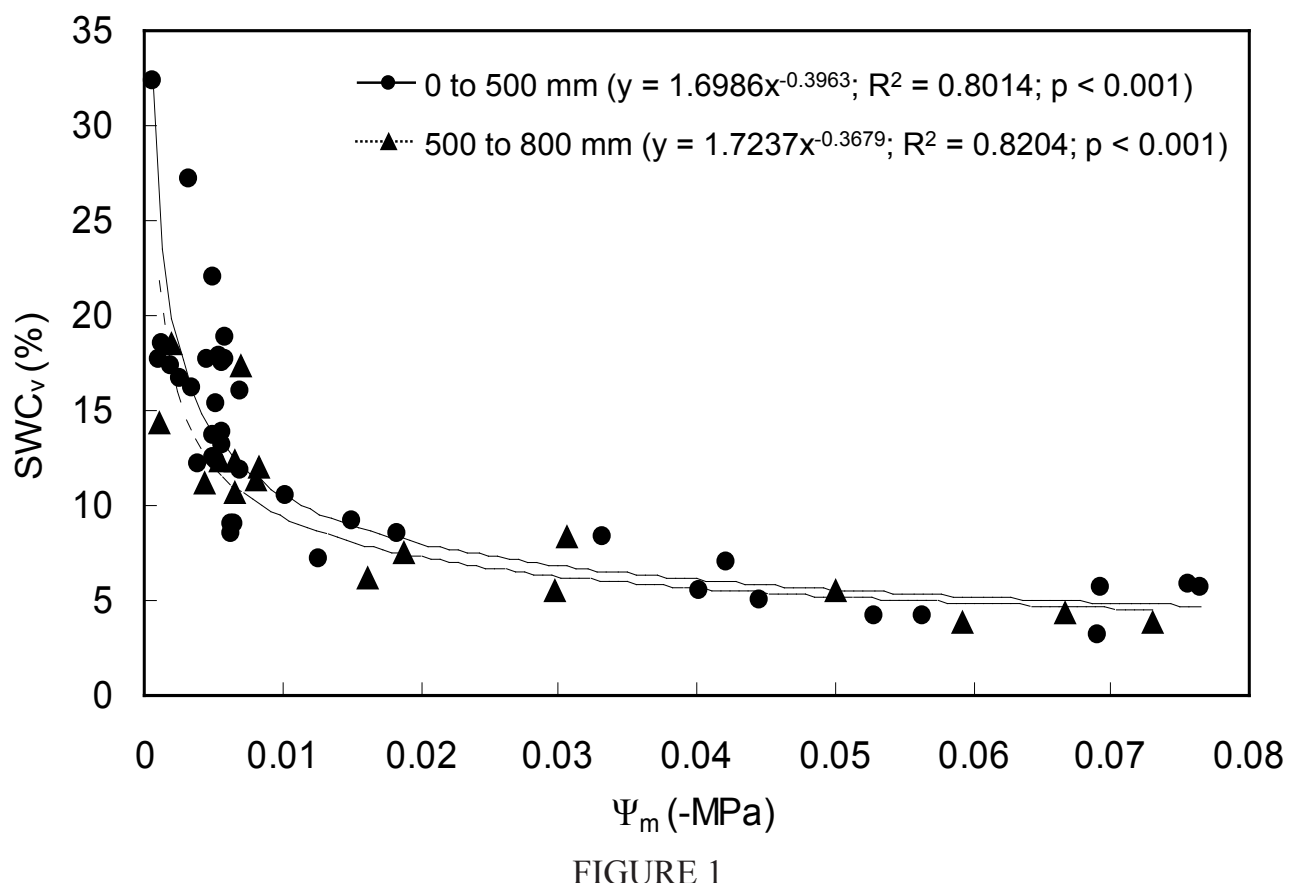

Soil water characteristic curves determined for two depth intervals in a lithic granite-gneiss soil near Augrabies in the Lower Orange River region.

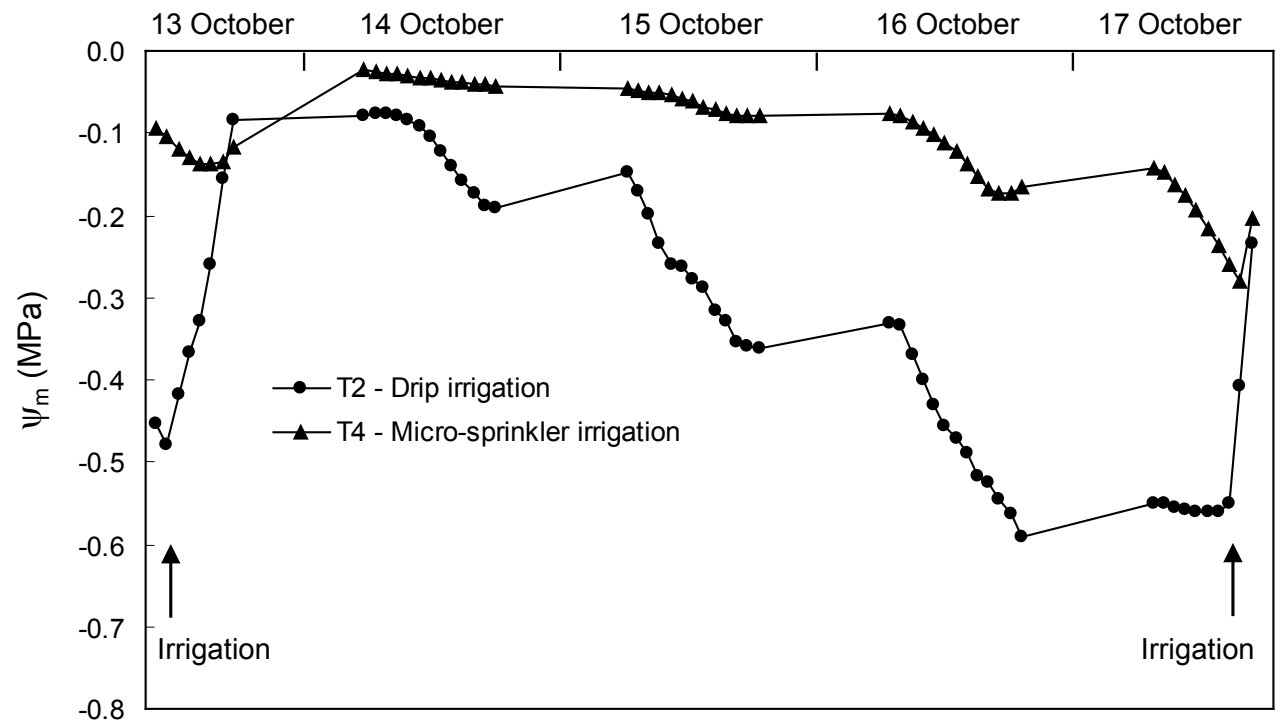

FIGURE 2

Effect of irrigation system on soil water matric potential $\left(\Psi_{\mathrm{m}}\right)$ between irrigations in a lithic granite-gneiss soil near Augrabies in the Lower Orange River region. 
substantially lower compared to the micro-sprinkler irrigated grapevines. Drippers also produced more grapes that did not have potential for fresh fruit marketing. The different irrigation systems had no effect on the storage capability of the grapes (Table 3). Sensorial colour and firmness of grapes produced by the frequently drip irrigated grapevines (T1) were poorer compared to micro-sprinkler applied once a week (T4). However, this did not reflect negatively in the general impression of the grapes (Table 3). Within an irrigation system, the different irrigation frequencies did not affect vegetative growth, yield, juice characteristics, export quality, storage capability or sensorial attributes.

\section{7/98 Season}

Frequent measuring of $\Psi_{\mathrm{m}}$ over a five-day period during October 1997 revealed that the drip irrigated soil dried out more rapidly than that wetted by the micro-sprinklers (Fig. 2). Consequently, $\Psi_{\mathrm{m}}$ dropped below $-0.02 \mathrm{MPa}$ within two days after drip irrigations. Slightly lower $\Psi_{\mathrm{m}}$ in the evening compared to the following morning was probably caused by the effect of air temperature variation on the mercury columns of the tensiometers. Due to the lower $\Psi_{\mathrm{m}}$, moderate water constraints occurred in the drip irrigated grapevines, whereas the micro-sprinkler irrigated grapevines only experienced mild constraints (Table 4). Within an irrigation system, irrigation frequency had no effect on grapevine water constraints. According to norms based on leaf blade contents at flowering (Conradie, 1994), grapevines did not experience any macro-element deficiencies, irrespective of irrigation system or frequency (Table 5). In fact, the drip irrigated grapevines (T1 \& T2) appeared to have been oversupplied with N. According to norms based on leaf blade Ca content at véraison, i.e. $1.5 \%$ to $2.4 \%$ (Conradie, 1994), excessively high $\mathrm{Ca}$ levels occurred in the micro-sprinkler irrigated grapevines (T3 \& T4).

The dry soil conditions in the 1996/97 season did not seem to have any negative carry-over effect on the number of bunches per grapevine in the 1997/98 season (Table 4).

TABLE 3

Effect of irrigation system and frequency on midday leaf water potential $\left(\Psi_{\mathrm{L}}\right)$, yield components, cane mass, juice characteristics and grape quality at harvest, as well as post-harvest sensorial attributes of Thompson Seedless table grapes during the 1996/97 season near Augrabies in the Lower Orange River region.

\begin{tabular}{|c|c|c|c|c|}
\hline & \multicolumn{2}{|c|}{ Drippers } & \multicolumn{2}{|c|}{ Micro-sprinklers } \\
\hline & $\begin{array}{c}\text { T1 - three times } \\
\text { per week }\end{array}$ & $\begin{array}{l}\text { T2 - once } \\
\text { per week }\end{array}$ & $\begin{array}{c}\text { T3 - three times } \\
\text { per week }\end{array}$ & $\begin{array}{l}\text { T4 - once } \\
\text { per week }\end{array}$ \\
\hline & \multicolumn{4}{|c|}{ Grapevine water status, yield components and cane mass } \\
\hline$\Psi_{\mathrm{L}}(\mathrm{MPa})$ & $-1.53 \mathrm{a}^{(1)}$ & $-1.72 b$ & $-1.43 \mathrm{a}$ & $-1.49 \mathrm{a}$ \\
\hline Bunches per grapevine & $30 \mathrm{a}$ & $26 \mathrm{a}$ & $31 \mathrm{a}$ & $29 \mathrm{a}$ \\
\hline Berry mass (g) & $2.7 \mathrm{~b}$ & $2.9 \mathrm{~b}$ & $3.3 \mathrm{a}$ & $3.6 \mathrm{a}$ \\
\hline Bunch mass (g) & $396 \mathrm{~b}$ & $442 \mathrm{~b}$ & $542 \mathrm{a}$ & $548 \mathrm{a}$ \\
\hline Yield (t/ha) & $16.2 \mathrm{~b}$ & $16.0 \mathrm{~b}$ & $22.1 \mathrm{a}$ & $22.3 \mathrm{a}$ \\
\hline \multirow[t]{2}{*}{ Cane mass $(\mathrm{t} / \mathrm{ha})$} & $2.4 \mathrm{~b}$ & $2.8 \mathrm{ab}$ & $3.0 \mathrm{ab}$ & $3.5 \mathrm{a}$ \\
\hline & \multicolumn{4}{|c|}{ Juice characteristics } \\
\hline $\mathrm{TSS}\left({ }^{\circ} \mathrm{B}\right)$ & $16.1 \mathrm{a}$ & $15.7 \mathrm{a}$ & $16.0 \mathrm{a}$ & $16.4 \mathrm{a}$ \\
\hline TTA $(\mathrm{g} / \mathrm{L})$ & $7.5 \mathrm{a}$ & $8.0 \mathrm{a}$ & $7.9 \mathrm{a}$ & $7.4 \mathrm{a}$ \\
\hline \multirow[t]{2}{*}{$\mathrm{pH}$} & $3.17 \mathrm{a}$ & $3.10 \mathrm{a}$ & $3.10 \mathrm{a}$ & $3.13 \mathrm{a}$ \\
\hline & \multicolumn{4}{|c|}{ Export quality at harvest } \\
\hline Export $(\%)$ & $57 \mathrm{~b}$ & $49 \mathrm{~b}$ & $77 \mathrm{a}$ & $83 \mathrm{a}$ \\
\hline Local (\%) & $19 \mathrm{a}$ & $20 \mathrm{a}$ & $18 \mathrm{a}$ & $13 \mathrm{a}$ \\
\hline \multirow[t]{2}{*}{ For juice production $(\%)$} & $23 \mathrm{a}$ & $31 \mathrm{a}$ & $7 \mathrm{~b}$ & $4 \mathrm{~b}$ \\
\hline & \multicolumn{4}{|c|}{ Storage capability } \\
\hline Loose berries (g/9 kg carton) & $41 \mathrm{a}$ & $28 \mathrm{a}$ & $41 \mathrm{a}$ & $68 \mathrm{a}$ \\
\hline $\mathrm{SO}_{2}$ damage (g/9 kg carton) & $30 \mathrm{a}$ & $0 \mathrm{a}$ & $44 \mathrm{a}$ & $31 \mathrm{a}$ \\
\hline \multirow[t]{2}{*}{ Berry crack (g/9 kg carton) } & $9 \mathrm{a}$ & $108 \mathrm{a}$ & $41 \mathrm{a}$ & $131 \mathrm{a}$ \\
\hline & \multicolumn{4}{|c|}{ Sensorial attributes following cold storage } \\
\hline Colour $^{(2)}$ & $-0.60 b$ & $-0.44 a b$ & $0.12 \mathrm{ab}$ & $0.92 \mathrm{a}$ \\
\hline Firmness $^{(2)}$ & $-0.67 b$ & $-0.17 \mathrm{ab}$ & $-0.37 \mathrm{ab}$ & $1.21 \mathrm{a}$ \\
\hline Taste $^{(2)}$ & $-0.14 \mathrm{a}$ & $-0.15 \mathrm{a}$ & $-0.46 \mathrm{a}$ & $0.75 \mathrm{a}$ \\
\hline General impression $^{(2)}$ & $-0.46 \mathrm{a}$ & $0.01 \mathrm{a}$ & $-0.16 \mathrm{a}$ & $0.62 \mathrm{a}$ \\
\hline
\end{tabular}

(1) Values designated by the same letter within each row do not differ significantly ( $\mathrm{p} \leq 0.05)$.

${ }^{(2)}$ Values are maximum likelihood estimators (Xbetas). 
TABLE 4

Effect of irrigation system and frequency on midday leaf water potential $\left(\Psi_{L}\right)$, cane mass, yield components, juice characteristics and grape quality at harvest, as well as post-harvest sensorial attributes of Thompson Seedless table grapes during the 1997/98 season near Augrabies in the Lower Orange River region.

\begin{tabular}{|c|c|c|c|c|}
\hline & \multicolumn{2}{|c|}{ Drippers } & \multicolumn{2}{|c|}{ Micro-sprinklers } \\
\hline & $\begin{array}{c}\text { T1 - three times } \\
\text { per week }\end{array}$ & $\begin{array}{c}\text { T2 - two times per } \\
\text { week }\end{array}$ & $\begin{array}{c}\text { T3 - three times } \\
\text { per week }\end{array}$ & $\begin{array}{c}\text { T4 - two times per } \\
\text { week }\end{array}$ \\
\hline & \multicolumn{4}{|c|}{ Grapevine water status, yield components and cane mass } \\
\hline$\Psi_{\mathrm{L}}(\mathrm{MPa})$ & $-1.39 b^{(1)}$ & $-1.40 b$ & $-1.22 \mathrm{a}$ & $-1.25 \mathrm{a}$ \\
\hline Bunches per grapevine & $30 \mathrm{a}$ & $26 \mathrm{a}$ & $31 \mathrm{a}$ & $29 \mathrm{a}$ \\
\hline Berry mass (g) & $4.1 \mathrm{~b}$ & $3.9 \mathrm{~b}$ & $4.9 \mathrm{a}$ & $5.0 \mathrm{a}$ \\
\hline Bunch mass (g) & $383 \mathrm{~b}$ & $258 \mathrm{~b}$ & $522 \mathrm{a}$ & 489 a \\
\hline Yield (t/ha) & $17.2 \mathrm{~b}$ & $16.5 \mathrm{~b}$ & $24.6 \mathrm{a}$ & $22.1 \mathrm{a}$ \\
\hline \multirow[t]{2}{*}{ Cane mass (t/ha) } & $4.3 \mathrm{~b}$ & $3.6 \mathrm{~b}$ & $6.1 \mathrm{a}$ & $6.2 \mathrm{a}$ \\
\hline & \multicolumn{4}{|c|}{ Juice characteristics } \\
\hline $\mathrm{TSS}\left({ }^{\circ} \mathrm{B}\right)$ & $21.9 \mathrm{a}$ & $22.1 \mathrm{a}$ & $20.5 \mathrm{~b}$ & $20.6 \mathrm{~b}$ \\
\hline TTA $(g / L)$ & $7.5 \mathrm{c}$ & $7.8 \mathrm{bc}$ & $8.7 \mathrm{a}$ & $8.1 \mathrm{~b}$ \\
\hline \multirow[t]{2}{*}{$\mathrm{pH}$} & $3.05 \mathrm{a}$ & $2.95 \mathrm{~b}$ & $3.00 \mathrm{ab}$ & $3.03 \mathrm{a}$ \\
\hline & \multicolumn{4}{|c|}{ Export quality at harvest } \\
\hline Export $(\%)$ & $55 \mathrm{~b}$ & $59 \mathrm{~b}$ & $74 \mathrm{a}$ & $75 \mathrm{a}$ \\
\hline Local $(\%)$ & $30 \mathrm{a}$ & $23 \mathrm{a}$ & $15 \mathrm{~b}$ & $12 \mathrm{~b}$ \\
\hline \multirow[t]{2}{*}{ For juice production (\%) } & $15 \mathrm{a}$ & $18 \mathrm{a}$ & $11 \mathrm{~b}$ & $12 \mathrm{~b}$ \\
\hline & \multicolumn{4}{|c|}{ Storage capability } \\
\hline Loose berries (g/9 kg carton) & $43 \mathrm{a}$ & $29 \mathrm{a}$ & $62 \mathrm{a}$ & $36 \mathrm{a}$ \\
\hline $\mathrm{SO}_{2}$ damage ( $\mathrm{g} / 9 \mathrm{~kg}$ carton $)$ & $37 \mathrm{a}$ & $20 \mathrm{a}$ & $59 \mathrm{a}$ & $33 \mathrm{a}$ \\
\hline \multirow[t]{2}{*}{ Berry crack (g/9 kg carton) } & $29 \mathrm{a}$ & $108 \mathrm{a}$ & $81 \mathrm{a}$ & $25 \mathrm{a}$ \\
\hline & \multicolumn{4}{|c|}{ Sensorial attributes following cold storage } \\
\hline Colour $^{(2)}$ & $-0.25 a b$ & $-0.48 b$ & $0.21 \mathrm{ab}$ & $0.53 \mathrm{a}$ \\
\hline Firmness $^{(2)}$ & $-0.22 \mathrm{ab}$ & $-0.90 b$ & $0.56 \mathrm{a}$ & $0.57 \mathrm{a}$ \\
\hline Taste $^{(2)}$ & $-0.34 b$ & $-0.06 \mathrm{ab}$ & $0.11 \mathrm{ab}$ & $0.29 \mathrm{a}$ \\
\hline General impression $^{(2)}$ & $-0.31 b$ & $-0.62 b$ & $0.39 \mathrm{a}$ & $0.54 \mathrm{a}$ \\
\hline
\end{tabular}

(1) Values designated by the same letter within each row do not differ significantly ( $\mathrm{p} \leq 0.05)$.

(2) Values are maximum likelihood estimators (Xbetas).

The rapid drying of the drip irrigated soil resulted in smaller berries compared to micro-sprinkler irrigation. This indicated that moderate water constraints induced by the specific drip irrigation frequencies were detrimental to berry development. Similar to the 1996/97 season, smaller berries produced by the drip irrigated grapevines resulted in lower bunch masses and yields compared to micro-sprinkler irrigation. Vegetative growth was substantially stronger in the 1997/98 season than in the 1996/97 season. However, cane mass of the drip irrigated grapevines was still lower compared to the microsprinkler irrigated grapevines (Table 4). Within an irrigation system, the different irrigation frequencies did not affect vegetative growth and yield components. Drip irrigation (T1 \& T2) resulted in higher berry sugar concentrations than micro-sprinklers (T3 \& T4) when the grapes were harvested on 8 December 1997 (Table 4). Drip irrigation also caused lower juice TTA compared to grapevines irrigated three times a week by means of micro-sprinklers (T3). In the case of micro-sprinklers, the lower frequency (T4) also resulted in lower TTA compared to T3. Drip irrigation applied at the lower frequency (T2) lowered the juice $\mathrm{pH}$ compared to more frequent irrigation, as well as micro-sprinkler irrigation applied at the lower frequency. Due to smaller berries and bunches, the export quality of the drip irrigated grapevines was $c a$. 20\% lower compared to the micro-sprinkler irrigated grapevines (Table 4). Drip irrigation produced more grapes that were only suitable for local markets, and grapevines that were not marketable at all. Similar to the 1996/97 season, the different irrigation system/frequency combinations had no effect on the storage capability of the grapes (Table 4). The sensorial colour and firmness of grapes produced on the less frequently micro-sprinkler irrigated grapevines (T4) were better than those produced on grapevines that were drip irrigated at the same frequency (T2). The firmness of 
TABLE 5

Effect of irrigation system and frequency on the nutrient status of Thompson Seedless table grapes determined at two growth stages during the 1997/98 season near Augrabies in the Lower Orange River region.

\begin{tabular}{|c|c|c|c|c|}
\hline \multirow[b]{2}{*}{ Stage } & \multicolumn{2}{|c|}{ Drippers } & \multicolumn{2}{|c|}{ Micro-sprinklers } \\
\hline & $\begin{array}{c}\text { T1 - three times } \\
\text { per week }\end{array}$ & $\begin{array}{c}\text { T2 - two times } \\
\text { per week }\end{array}$ & $\begin{array}{c}\text { T3 - three times } \\
\text { per week }\end{array}$ & $\begin{array}{c}\text { T4 - two times per } \\
\text { week }\end{array}$ \\
\hline & \multicolumn{4}{|c|}{ Nitrogen $(\%)$} \\
\hline Flowering & $2.81 \mathrm{a}^{(1)}$ & $2.77 \mathrm{a}$ & $2.50 \mathrm{a}$ & $2.69 \mathrm{a}$ \\
\hline \multirow[t]{2}{*}{ Véraison } & $2.21 \mathrm{a}$ & $2.05 \mathrm{a}$ & $1.90 \mathrm{a}$ & $1.97 \mathrm{a}$ \\
\hline & \multicolumn{4}{|c|}{ Phosphorus (\%) } \\
\hline Flowering & $0.42 \mathrm{a}$ & $0.41 \mathrm{a}$ & $0.51 \mathrm{a}$ & $0.55 \mathrm{a}$ \\
\hline \multirow[t]{2}{*}{ Véraison } & $0.34 \mathrm{a}$ & $0.33 \mathrm{a}$ & $0.50 \mathrm{a}$ & $0.53 \mathrm{a}$ \\
\hline & \multicolumn{4}{|c|}{ Potassium (\%) } \\
\hline Flowering & $0.91 \mathrm{a}$ & $1.16 \mathrm{a}$ & $1.16 \mathrm{a}$ & $1.13 \mathrm{a}$ \\
\hline \multirow[t]{2}{*}{ Véraison } & $1.10 \mathrm{a}$ & $1.09 \mathrm{a}$ & $1.16 \mathrm{a}$ & $1.18 \mathrm{a}$ \\
\hline & \multicolumn{4}{|c|}{ Calcium (\%) } \\
\hline Flowering & $2.04 \mathrm{a}$ & $1.91 \mathrm{a}$ & $2.23 \mathrm{a}$ & $2.20 \mathrm{a}$ \\
\hline \multirow[t]{2}{*}{ Véraison } & $2.25 \mathrm{a}$ & $2.29 \mathrm{a}$ & $2.77 \mathrm{a}$ & $2.91 \mathrm{a}$ \\
\hline & \multicolumn{4}{|c|}{ Magnesium (\%) } \\
\hline Flowering & $0.40 \mathrm{a}$ & $0.37 \mathrm{a}$ & $0.36 \mathrm{a}$ & $0.37 \mathrm{a}$ \\
\hline Véraison & $0.33 \mathrm{a}$ & $0.34 \mathrm{a}$ & $0.32 \mathrm{a}$ & $0.36 \mathrm{a}$ \\
\hline
\end{tabular}

(1) Values designated by the same letter within each row do not differ significantly $(\mathrm{p} \leq 0.05)$.

grapes produced by more frequent micro-sprinkler irrigation was also better than that of the $\mathrm{T} 2$ grapes. Taste of grapes produced by more frequently drip irrigated grapevines (T1) was poorer than the T4 grapevines. These trends in sensorial attributes had a negative effect on the general impression of the drip irrigated grapevines compared to the micro-sprinkler irrigated grapevines. Within each irrigation system, irrigation frequency did not affect export quality, storage capability or sensorial attributes.

\section{8/99 Season}

When drip irrigation was applied daily from the 1998/99 season onwards, $\Psi_{\mathrm{m}}$ remained above $-0.02 \mathrm{MPa}$ (data not shown). According to the $\Psi_{\mathrm{PD}}$ classification proposed by Deloire et al. (2004), the drip irrigated grapevines experienced moderate water constraints compared to mild constraints in the micro-sprinkler irrigated grapevines (Table 6). This indicated that the water status in micro-sprinkler irrigated grapevines recovered better during the night than the drip irrigated grapevines. It must be noted that under the given atmospheric and soil conditions, grapevines were not able to fully recover during the night, i.e. $\Psi_{\mathrm{PD}}$ was still lower than -0.2 MPa (Deloire et al., 2004). Around midday, grapevines experienced moderate water constraints, irrespective of the irrigation system/frequency combination. This showed that the daily drip irrigation was able to maintain the same levels of daytime water constraints as less frequently applied micro-sprinkler irrigation. Similar to the 1997/98 season, grapevines did not experience any macro-element deficiencies from bud break until harvest, irrespective of irrigation system or frequency (Table 7). Excessively high $\mathrm{Ca}$ levels at véraison again occurred in the T1, T3 \&
T4 grapevines. Compared to the other seasons, grapevine fertility was considerably lower in the 1998/99 season (Table 6). Low grapevine fertility caused by adverse atmospheric conditions commonly occurs in Thompson Seedless vineyards in the Lower Orange River region (Myburgh, 2008). However, this does not rule out the possibility that fertility of the T1 grapevines was further reduced by dry soil conditions in the preceding winter (Myburgh, 2003a, 2003c; Myburgh \& Van der Walt, 2005). Drip irrigation during the warmest part of the day (T2) resulted in smaller berries compared to T1 and T3 (Table 6). However, berry size was still acceptable for export quality, irrespective of the irrigation system/frequency combination. This indicated that moderate daytime water constraints allowed sufficient berry development at the low crop loads. Smaller berries produced by the drip irrigated grapevines not only tended to reduce bunch masses, but also resulted in lower yields compared to micro-sprinkler irrigation applied twice a week (T4). Daily drip irrigation produced the same vegetative growth as micro-sprinkler irrigation (Table 6). Within an irrigation system, the different irrigation frequencies did not affect vegetative growth or yield components.

The different irrigation system/frequency combinations had no effect on juice TSS, TTA or $\mathrm{pH}$ at harvest on 11 December 1998, except for lower $\mathrm{pH}$ in the T3 grapes (Table 6). It should be noted that the lower crop loads in the 1998/99 season did not enhance the rate of berry ripening compared to the higher crop load in the previous season. Due to smaller berries and bunches, the export quality of grapevines which received drip irrigation during the warmest part of the day (T2) was lower compared to other irrigation system/frequency combinations (Table 6). The poorer export 
quality of the $\mathrm{T} 2$ grapes was probably caused by the smaller berry size as mentioned above. Micro-sprinkler irrigation applied at the lower frequency (T4) produced fewer grapes that were not suitable for fresh fruit marketing than the other treatments. Different irrigation system/frequency combinations had no effect on the storage capability of the grapes (Table 6). Sensorial colour and firmness of grapes were not affected by any of the treatments. However, in the case of micro-sprinkler irrigated grapevines, taste and general impression of grapes produced by less frequent irrigation (T4) were superior compared to the higher frequency (T3). Grape taste showed a similar trend, except that the taste of $\mathrm{T} 1$ grapes was poorer than that of the T4 grapevines. Drip irrigation did not induce any negative effects on sensorial attributes compared to micro-sprinkler irrigation. This indicated that daily drip irrigation had a positive effect on grape quality compared to the less frequent drip irrigations applied in the first two seasons.

\section{9/2000 Season}

Grapevines experienced moderate predawn and midday water constraints, irrespective of the irrigation system/ frequency combination (Table 8). This confirmed that daily drip irrigation was able to maintain the same levels of water constraints in grapevines as micro-sprinkler irrigation. Furthermore, it was evident that grapevine water status in all treatments did not fully recover during the night under the given atmospheric and soil conditions. Grapevine fertility was comparable to the 1996/97 and 1997/98 seasons (Table 8). The different irrigation systems did not affect berry

\section{TABLE 6}

Effect of irrigation system and frequency on predawn $\left(\Psi_{P D}\right)$ and midday $\left(\Psi_{L}\right)$ leaf water potential, cane mass, yield components, juice characteristics and grape quality at harvest, as well as post-harvest sensorial attributes of Thompson Seedless table grapes during the 1998/99 season near Augrabies in the Lower Orange River region.

\begin{tabular}{|c|c|c|c|c|}
\hline & \multicolumn{2}{|c|}{ Drippers } & \multicolumn{2}{|c|}{ Micro-sprinklers } \\
\hline & $\begin{array}{c}\text { T1 - daily during } \\
\text { early morning }\end{array}$ & $\begin{array}{c}\text { T2 - daily around } \\
\text { noon }\end{array}$ & $\begin{array}{c}\text { T3 - three times } \\
\text { per week }\end{array}$ & $\begin{array}{c}\text { T4 - two times per } \\
\text { week }\end{array}$ \\
\hline & \multicolumn{4}{|c|}{ Grapevine water status, yield components and cane mass } \\
\hline$\Psi_{\mathrm{PD}}(\mathrm{MPa})$ & $-0.44 b^{(1)}$ & $-0.46 b$ & $-0.31 \mathrm{a}$ & $-0.35 \mathrm{a}$ \\
\hline$\Psi_{\mathrm{L}}(\mathrm{MPa})$ & $-1.42 \mathrm{a}$ & $-1.45 \mathrm{a}$ & $-1.39 \mathrm{a}$ & $-1.41 \mathrm{a}$ \\
\hline Bunches per grapevine & $15 \mathrm{~b}$ & $17 \mathrm{ab}$ & $16 a b$ & $19 \mathrm{a}$ \\
\hline Berry mass (g) & $6.5 \mathrm{a}$ & $6.0 \mathrm{~b}$ & $6.9 \mathrm{a}$ & $6.3 \mathrm{ab}$ \\
\hline Bunch mass (g) & $681 \mathrm{a}$ & $663 \mathrm{a}$ & $749 \mathrm{a}$ & $744 \mathrm{a}$ \\
\hline Yield (t/ha) & $13.8 \mathrm{~b}$ & $15.5 \mathrm{~b}$ & $16.7 \mathrm{ab}$ & $19.1 \mathrm{a}$ \\
\hline \multirow[t]{2}{*}{ Cane mass (t/ha) } & $5.6 \mathrm{a}$ & $6.6 \mathrm{a}$ & $6.5 \mathrm{a}$ & $5.2 \mathrm{a}$ \\
\hline & \multicolumn{4}{|c|}{ Juice characteristics } \\
\hline $\operatorname{TSS}\left({ }^{\circ} \mathrm{B}\right)$ & $19.0 \mathrm{a}$ & $17.9 \mathrm{a}$ & $17.4 \mathrm{a}$ & $17.9 \mathrm{a}$ \\
\hline TTA $(g / L)$ & $8.5 \mathrm{a}$ & $9.1 \mathrm{a}$ & $8.8 \mathrm{a}$ & $7.9 \mathrm{a}$ \\
\hline \multirow[t]{2}{*}{$\mathrm{pH}$} & $3.30 \mathrm{a}$ & $3.23 \mathrm{a}$ & $3.20 \mathrm{~b}$ & $3.23 \mathrm{a}$ \\
\hline & \multicolumn{4}{|c|}{ Export quality at harvest } \\
\hline Export (\%) & $89 \mathrm{a}$ & $74 \mathrm{~b}$ & $83 \mathrm{a}$ & $88 \mathrm{a}$ \\
\hline Local $(\%)$ & $6 \mathrm{a}$ & $16 \mathrm{a}$ & $8 \mathrm{a}$ & $9 \mathrm{a}$ \\
\hline \multirow[t]{2}{*}{ For juice production $(\%)$} & $5 \mathrm{ab}$ & $9 \mathrm{a}$ & $9 \mathrm{a}$ & $4 \mathrm{~b}$ \\
\hline & \multicolumn{4}{|c|}{ Storage capability } \\
\hline Loose berries (g/9 kg carton) & $31 \mathrm{a}$ & $96 \mathrm{a}$ & $82 \mathrm{a}$ & $92 \mathrm{a}$ \\
\hline $\mathrm{SO}_{2}$ damage (g/9 kg carton) & $6 \mathrm{a}$ & $14 \mathrm{a}$ & $35 \mathrm{a}$ & $29 \mathrm{a}$ \\
\hline \multirow[t]{2}{*}{ Berry crack (g/9 kg carton) } & $161 \mathrm{a}$ & $254 \mathrm{a}$ & $157 \mathrm{a}$ & $371 \mathrm{a}$ \\
\hline & \multicolumn{4}{|c|}{ Sensorial attributes following cold storage } \\
\hline Colour $^{(2)}$ & $0.09 \mathrm{a}$ & $-0.35 \mathrm{a}$ & $0.00 \mathrm{a}$ & $0.27 \mathrm{a}$ \\
\hline Firmness $^{(2)}$ & $-0.14 \mathrm{a}$ & $-0.03 \mathrm{a}$ & $-0.05 \mathrm{a}$ & $0.12 \mathrm{a}$ \\
\hline Taste $^{(2)}$ & $-0.01 \mathrm{ab}$ & $0.20 \mathrm{ab}$ & $-0.52 b$ & $0.33 \mathrm{a}$ \\
\hline General impression $^{(2)}$ & $-0.13 a b$ & $-0.06 \mathrm{ab}$ & $-0.38 b$ & $0.56 \mathrm{a}$ \\
\hline
\end{tabular}

(1) Values designated by the same letter within each row do not differ significantly ( $\mathrm{p} \leq 0.05)$.

(2) Values are maximum likelihood estimators (Xbetas). 
mass, but drip irrigation reduced bunch mass compared to micro-sprinkler irrigation applied at the higher frequency (T3). There is no explanation why drip irrigation seemed to have produced fewer berries per bunch in this particular season. Within an irrigation system, the different irrigation frequencies did not affect yield components or vegetative growth. Drip irrigation increased juice TSS and reduced TTA compared to micro-sprinkler irrigation applied at the higher frequency (T3) at harvest on 17 December 1999 (Table 8). The different irrigation system/frequency combinations had no effect on juice $\mathrm{pH}$. Colour and taste of grapes were not affected by any of the treatments. Drip irrigation during the day (T2) reduced firmness compared to drip applied early in the morning (T1). Less frequent micro-sprinkler irrigation (T4) produced grapes with a better overall appearance than the more frequently irrigated grapevines (T3). Drip irrigation did not induce any negative effects on sensorial attributes compared to micro-sprinkler irrigation. The 1999/2000 season's results confirmed that the daily drip irrigation had a positive effect on grape quality compared to the less frequent drip irrigations applied in the first two seasons.

\section{Weed growth}

Drip irrigation invariably suppressed weed growth compared to micro-sprinkler irrigation, except in the 1996/97 season when the more frequent micro-sprinkler irrigation (T3) increased DMP compared to all the treatments (Table 9). These results indicated that the smaller wetted area under the drippers suppressed weed growth substantially compared to full surface irrigation. With the exception of the 1998/99 season, more frequent micro-sprinkler irrigation (T3) also increased DMP compared to less frequent irrigation (T4). The DMP of summer weeds under micro-sprinkler irrigation (Table 9) was substantially lower compared to an average

TABLE 7

Effect of irrigation system and frequency on the nutrient status of Thompson Seedless table grapes determined at four growth stages during the 1998/99 season near Augrabies in the Lower Orange River region.

\begin{tabular}{|c|c|c|c|c|}
\hline \multirow[b]{2}{*}{ Stage } & \multicolumn{2}{|c|}{ Drippers } & \multicolumn{2}{|c|}{ Micro-sprinklers } \\
\hline & $\begin{array}{l}\text { T1 - daily during } \\
\text { early morning }\end{array}$ & $\begin{array}{c}\text { T2 - daily around } \\
\text { noon }\end{array}$ & $\begin{array}{c}\text { T3 - three times } \\
\text { per week }\end{array}$ & $\begin{array}{c}\text { T4 - two times per } \\
\text { week }\end{array}$ \\
\hline & \multicolumn{4}{|c|}{ Nitrogen (\%) } \\
\hline Bud break & $3.71 \mathrm{a}^{(1)}$ & $3.31 \mathrm{a}$ & $3.60 \mathrm{a}$ & $3.72 \mathrm{a}$ \\
\hline Flowering & $2.30 \mathrm{a}$ & $2.54 \mathrm{a}$ & $2.52 \mathrm{a}$ & $2.43 \mathrm{a}$ \\
\hline Pea size berries & $2.60 \mathrm{a}$ & $2.66 \mathrm{a}$ & $2.32 \mathrm{a}$ & $2.40 \mathrm{a}$ \\
\hline \multirow[t]{2}{*}{ Véraison } & $2.43 \mathrm{a}$ & $2.44 \mathrm{a}$ & $2.17 \mathrm{a}$ & $2.29 \mathrm{a}$ \\
\hline & \multicolumn{4}{|c|}{ Phosphorus (\%) } \\
\hline Bud break & $0.51 \mathrm{a}$ & $0.49 \mathrm{a}$ & $0.74 \mathrm{a}$ & $0.70 \mathrm{a}$ \\
\hline Flowering & $0.37 \mathrm{a}$ & $0.37 \mathrm{a}$ & $0.51 \mathrm{a}$ & $0.47 \mathrm{a}$ \\
\hline Pea size berries & $0.41 \mathrm{a}$ & $0.44 \mathrm{a}$ & $0.44 \mathrm{a}$ & $0.43 \mathrm{a}$ \\
\hline \multirow[t]{2}{*}{ Véraison } & $0.47 \mathrm{a}$ & $0.49 \mathrm{a}$ & $0.50 \mathrm{a}$ & $0.49 \mathrm{a}$ \\
\hline & \multicolumn{4}{|c|}{ Potassium (\%) } \\
\hline Bud break & $0.74 \mathrm{a}^{(1)}$ & $0.94 \mathrm{a}$ & $1.18 \mathrm{a}$ & $1.27 \mathrm{a}$ \\
\hline Flowering & $0.85 \mathrm{a}$ & $1.16 \mathrm{a}$ & $1.24 \mathrm{a}$ & $1.22 \mathrm{a}$ \\
\hline Pea size berries & $0.97 \mathrm{a}$ & $1.19 \mathrm{a}$ & $1.29 \mathrm{a}$ & $1.44 \mathrm{a}$ \\
\hline \multirow[t]{2}{*}{ Véraison } & $0.88 \mathrm{a}$ & $1.18 \mathrm{a}$ & $1.14 \mathrm{a}$ & $1.51 \mathrm{a}$ \\
\hline & \multicolumn{4}{|c|}{ Calcium (\%) } \\
\hline Bud break & $1.29 \mathrm{a}$ & $1.59 \mathrm{a}$ & $1.66 \mathrm{a}$ & $1.75 \mathrm{a}$ \\
\hline Flowering & $1.77 \mathrm{a}$ & $2.14 \mathrm{a}$ & $2.24 \mathrm{a}$ & $2.39 \mathrm{a}$ \\
\hline Pea size berries & $1.60 \mathrm{a}$ & $2.01 \mathrm{a}$ & $2.07 \mathrm{a}$ & $2.28 \mathrm{a}$ \\
\hline \multirow[t]{2}{*}{ Véraison } & $1.89 \mathrm{a}$ & $2.52 \mathrm{a}$ & $2.38 \mathrm{a}$ & $2.67 \mathrm{a}$ \\
\hline & \multicolumn{4}{|c|}{ Magnesium (\%) } \\
\hline Bud break & $0.24 \mathrm{a}$ & $0.32 \mathrm{a}$ & $0.31 \mathrm{a}$ & $0.31 \mathrm{a}$ \\
\hline Flowering & $0.33 \mathrm{a}$ & $0.44 \mathrm{a}$ & $0.39 \mathrm{a}$ & $0.40 \mathrm{a}$ \\
\hline Pea size berries & $0.32 \mathrm{a}$ & $0.42 \mathrm{a}$ & $0.38 \mathrm{a}$ & $0.39 \mathrm{a}$ \\
\hline Véraison & $0.35 \mathrm{a}$ & $0.48 \mathrm{a}$ & $0.42 \mathrm{a}$ & $0.46 \mathrm{a}$ \\
\hline
\end{tabular}

(1) Values designated by the same letter within each row do not differ significantly ( $\mathrm{p} \leq 0.05)$. 
DMP of $1.44 \mathrm{t} /$ ha produced between véraison and harvest where weeds were mechanically controlled in a microsprinkler irrigated Thompson Seedless table grape vineyard in the Lower Orange River region (Fourie, 2005). However, the weed DMP was comparable to the $0.4 \mathrm{t} /$ ha where summer weeds were slashed four times, followed by herbicide application at véraison. The DMP of leaves and shoots of Thompson Seedless grapevines in the Lower Orange River

TABLE 8

Effect of irrigation system and frequency on predawn $\left(\Psi_{\mathrm{PD}}\right)$ and midday $\left(\Psi_{\mathrm{L}}\right)$ leaf water potential, cane mass, yield components, juice characteristics and grape quality at harvest, as well as post-harvest sensorial attributes of Thompson Seedless table grapes during the 1999/2000 season near Augrabies in the Lower Orange River region.

\begin{tabular}{|c|c|c|c|c|}
\hline & \multicolumn{2}{|c|}{ Drippers } & \multicolumn{2}{|c|}{ Micro-sprinklers } \\
\hline & $\begin{array}{c}\text { T1 - daily during } \\
\text { early morning }\end{array}$ & $\begin{array}{c}\mathrm{T} 2 \text { - daily around } \\
\text { noon }\end{array}$ & $\begin{array}{c}\text { T3 - three times } \\
\text { per week }\end{array}$ & $\begin{array}{c}\text { T4 - two times per } \\
\text { week }\end{array}$ \\
\hline & \multicolumn{4}{|c|}{ Grapevine water status, yield components and cane mass } \\
\hline$\Psi_{\mathrm{PD}}(\mathrm{MPa})$ & $-0.41 a^{(1)}$ & $-0.42 \mathrm{a}$ & $-0.40 \mathrm{a}$ & $-0.45 \mathrm{a}$ \\
\hline$\Psi_{\mathrm{L}}(\mathrm{MPa})$ & $-1.38 \mathrm{a}$ & $-1.40 \mathrm{a}$ & $-1.38 \mathrm{a}$ & $-1.42 \mathrm{a}$ \\
\hline Bunches per grapevine & $31 \mathrm{~b}$ & $29 \mathrm{~b}$ & $31 \mathrm{~b}$ & $35 \mathrm{a}$ \\
\hline Berry mass (g) & $6.0 \mathrm{a}$ & $6.2 \mathrm{a}$ & $6.0 \mathrm{a}$ & $6.1 \mathrm{a}$ \\
\hline Bunch mass (g) & $609 \mathrm{~b}$ & $594 \mathrm{~b}$ & $726 \mathrm{a}$ & $638 \mathrm{ab}$ \\
\hline Yield (t/ha) & $25.6 \mathrm{~b}$ & $23.0 \mathrm{~b}$ & $30.5 \mathrm{a}$ & $30.6 \mathrm{a}$ \\
\hline \multirow[t]{2}{*}{ Cane mass (t/ha) } & $4.4 \mathrm{a}$ & $5.0 \mathrm{a}$ & $4.3 \mathrm{a}$ & $3.9 \mathrm{a}$ \\
\hline & \multicolumn{4}{|c|}{ Juice characteristics } \\
\hline $\mathrm{TSS}\left({ }^{\circ} \mathrm{B}\right)$ & $17.5 \mathrm{a}$ & $17.3 \mathrm{a}$ & $15.5 \mathrm{~b}$ & $16.7 \mathrm{ab}$ \\
\hline TTA $(\mathrm{g} / \mathrm{L})$ & $9.5 \mathrm{~b}$ & $9.1 \mathrm{~b}$ & $11.6 \mathrm{a}$ & $10.5 \mathrm{ab}$ \\
\hline \multirow[t]{2}{*}{$\mathrm{pH}$} & $4.08 \mathrm{a}$ & $4.15 \mathrm{a}$ & $4.10 \mathrm{a}$ & $4.08 \mathrm{a}$ \\
\hline & \multicolumn{4}{|c|}{ Export quality at harvest } \\
\hline Export (\%) & $76 \mathrm{a}$ & $76 \mathrm{a}$ & $84 \mathrm{a}$ & $84 \mathrm{a}$ \\
\hline Local (\%) & $6 \mathrm{a}$ & $6 \mathrm{a}$ & $10 \mathrm{a}$ & $7 \mathrm{a}$ \\
\hline \multirow[t]{2}{*}{ For juice production (\%) } & $4 \mathrm{a}$ & $4 \mathrm{a}$ & $4 \mathrm{a}$ & $3 \mathrm{a}$ \\
\hline & \multicolumn{4}{|c|}{ Sensorial attributes following cold storage } \\
\hline Colour $^{(2)}$ & $0.14 \mathrm{a}$ & $-0.18 \mathrm{a}$ & $0.28 \mathrm{a}$ & $-0.25 \mathrm{a}$ \\
\hline Firmness $^{(2)}$ & $0.32 \mathrm{a}$ & $-0.40 \mathrm{~b}$ & $0.23 \mathrm{ab}$ & $-0.14 \mathrm{ab}$ \\
\hline Taste $^{(2)}$ & $-0.00 \mathrm{a}$ & $-0.12 \mathrm{a}$ & $0.06 \mathrm{a}$ & $0.06 \mathrm{a}$ \\
\hline General impression $^{(2)}$ & $-0.13 a b$ & $-0.06 \mathrm{ab}$ & $-0.38 b$ & $0.56 \mathrm{a}$ \\
\hline
\end{tabular}

(1) Values designated by the same letter within each row do not differ significantly $(\mathrm{p} \leq 0.05)$.

${ }^{(2)}$ Values are maximum likelihood estimators (Xbetas).

TABLE 9

Effect of irrigation system and frequency on dry matter production (DMP) of summer weeds as measured in April during four seasons in a Thompson Seedless vineyard near Augrabies in the Lower Orange River region.

\begin{tabular}{|c|c|c|c|c|}
\hline \multirow{3}{*}{ Season } & \multicolumn{4}{|c|}{$\operatorname{DMP}(\mathrm{t} / \mathrm{ha})$} \\
\hline & \multicolumn{2}{|c|}{ Drippers } & \multicolumn{2}{|c|}{ Micro-sprinklers } \\
\hline & $\mathbf{T} \mathbf{1}^{(1)}$ & $\mathbf{T} 2^{(1)}$ & $\mathbf{T 3}^{(1)}$ & $\mathbf{T} 4^{(1)}$ \\
\hline $1996 / 97$ & $0.09 \mathrm{~b}^{(2)}$ & $0.05 \mathrm{~b}$ & $0.31 \mathrm{a}$ & $0.13 \mathrm{~b}$ \\
\hline $1997 / 98$ & $0.04 \mathrm{c}$ & $0.03 \mathrm{c}$ & $0.35 \mathrm{a}$ & $0.22 \mathrm{~b}$ \\
\hline $1998 / 99$ & $0.03 \mathrm{~b}$ & $0.06 \mathrm{~b}$ & $0.37 \mathrm{a}$ & $0.23 \mathrm{a}$ \\
\hline $1999 / 2000$ & $0.05 \mathrm{c}$ & $0.05 \mathrm{c}$ & $0.44 \mathrm{a}$ & $0.26 \mathrm{~b}$ \\
\hline
\end{tabular}

(1) Refer to Tables 3, 4, 6 \& 8 for explanation of the irrigation frequencies during the different seasons.

(2) Values designated by the same letter within each row do not differ significantly $(p \leq 0.05)$. 
region is approximately $2.5 \mathrm{t} / \mathrm{ha}$ (W.J. Conradie \& P. Raath, unpublished data). The mean weed DMP during the four seasons amounted to $12 \%$ of the seasonal grapevine DMP in autumn. This suggested that the weeds probably increased vineyard ET, particularly during late summer and winter. Determining the contribution of the weed growth to ET was beyond the scope of the study. Since the drip irrigated soil was almost weed-free, it was unlikely that weed growth

\section{TABLE 10}

Mean daily reference evapotranspiration $\left(\mathrm{ET}_{\mathrm{o}}\right)$ for the duration of the field trial, as well as effect of irrigation system and frequency on daily evapotranspiration (ET) of Thompson Seedless table grapes near Augrabies in the Lower Orange River region. Drip irrigation values are means for 1998/99 and 1999/2000 seasons, whereas micro-sprinkler values are means for $1997 / 98$ to $1999 / 2000$ seasons.

\begin{tabular}{|c|c|c|c|c|c|}
\hline \multirow{3}{*}{ Month } & \multirow{3}{*}{$\begin{array}{c}\mathbf{E T}_{0} \\
(\mathrm{~mm} / \text { day })\end{array}$} & \multicolumn{4}{|c|}{ ET (mm/day) } \\
\hline & & \multicolumn{2}{|c|}{ Drippers } & \multicolumn{2}{|c|}{ Micro-sprinklers } \\
\hline & & $\begin{array}{l}\text { T1 - daily during } \\
\text { early morning }\end{array}$ & $\begin{array}{c}\text { T2 - daily around } \\
\text { noon }\end{array}$ & $\begin{array}{c}\text { T3 - three times } \\
\text { per week }\end{array}$ & $\begin{array}{c}\text { T4 - two times } \\
\text { per week }\end{array}$ \\
\hline August & 4.2 & 1.2 & 1.1 & 2.5 & 2.3 \\
\hline September & 5.5 & 1.6 & 1.4 & 4.2 & 3.3 \\
\hline October & 7.4 & 1.9 & 2.5 & 6.3 & 5.9 \\
\hline November & 8.4 & 2.4 & 3.0 & 7.6 & 7.2 \\
\hline December & 8.9 & 3.0 & 3.4 & 8.4 & 8.0 \\
\hline January & 8.9 & 3.6 & 3.1 & 8.6 & 7.9 \\
\hline February & 7.2 & 2.3 & 2.6 & 6.9 & 6.5 \\
\hline March & 5.7 & 2.0 & 2.0 & 5.1 & 4.4 \\
\hline April & 4.4 & 1.5 & 1.7 & 3.8 & 3.8 \\
\hline May & 3.3 & 1.2 & 1.0 & 2.6 & 2.3 \\
\hline June & 3.0 & 1.0 & 0.7 & 1.8 & 1.8 \\
\hline July & 3.3 & 0.5 & 0.6 & 1.2 & 1.4 \\
\hline Total $(\mathrm{mm} /$ & & 675 & 702 & 1788 & 1660 \\
\hline
\end{tabular}

TABLE 11

Mean monthly crop coefficients for drip and micro-sprinkler irrigated Thompson Seedless table grapes near Augrabies in the Lower Orange River region. Values for drip irrigation are means for 1998/99 and 1999/2000 seasons, whereas micro-sprinkler values are means for $1997 / 98$ to $1999 / 2000$ seasons.

\begin{tabular}{lcccc}
\hline \multirow{2}{*}{ Month } & \multicolumn{3}{c}{$\mathbf{k}_{\mathbf{c}}$} \\
\cline { 2 - 5 } & \multicolumn{3}{c}{ Drippers } & \multicolumn{2}{c}{ Micro-sprinklers } \\
\cline { 2 - 5 } & $\begin{array}{c}\text { T1 - daily during } \\
\text { early morning }\end{array}$ & $\begin{array}{c}\text { T2 - daily around } \\
\text { noon }\end{array}$ & $\begin{array}{c}\text { T3 - three times } \\
\text { per week }\end{array}$ & $\begin{array}{c}\text { T4 - two times } \\
\text { per week }\end{array}$ \\
\hline August & 0.27 & 0.26 & 0.61 & 0.55 \\
September & 0.28 & 0.25 & 0.77 & 0.61 \\
October & 0.30 & 0.34 & 0.85 & 0.79 \\
November & 0.32 & 0.36 & 0.91 & 0.86 \\
December & 0.36 & 0.38 & 0.94 & 0.90 \\
January & 0.37 & 0.34 & 0.96 & 0.88 \\
February & 0.34 & 0.37 & 0.95 & 0.90 \\
March & 0.36 & 0.36 & 0.90 & 0.77 \\
April & 0.36 & 0.39 & 0.85 & 0.87 \\
May & 0.33 & 0.30 & 0.80 & 0.70 \\
June & 0.27 & 0.23 & 0.59 & 0.60 \\
July & 0.18 & 0.19 & 0.35 & 0.41 \\
\hline
\end{tabular}


impacted significantly on ET in the case of T1 and T2.

\section{Evapotranspiration and crop coefficients}

Due to the poor performance of the drip irrigated grapevines (T1 \& T2) in the first two seasons, daily ET was only calculated for the 1998/99 and 1999/2000 seasons. Likewise, ET for the 1996/97 season was not considered in the case of the micro-sprinkler irrigated grapevines (T3 \& T4). On a monthly basis, mean daily ET of drip irrigated grapevines was considerably lower than that of micro-sprinkler irrigated grapevines (Table 10). Similarly, drip irrigated Barlinka table grapes in the Hex River valley required $c a$. $28 \%$ less irrigation compared to micro-sprinklers (Saayman \& Lambrechts, 1995). Since vegetative growth of drip and micro-sprinkler irrigated grapevines was comparable in the 1998/99 and 1999/2000 seasons, transpiration losses would be expected to be similar for the two irrigation systems. Hence, the differences in ET were primarily caused by less evaporation from the smaller surface area wetted by the drippers (Myburgh, 1998). The foregoing does not rule out the possibility that weed growth (Table 9) could have contributed to the ET of T3 and T4 during late summer and winter. The ET of more frequently micro-sprinkler irrigated grapevines (T3) was almost invariably higher from September until April compared to those that received irrigation two times per week (T4). This trend confirmed earlier reports, which showed that ET of micro-sprinkler irrigated vineyards on horizontally orientated trellis systems increased as the irrigation frequency increases (Myburgh, 2003b; Myburgh $\&$ Howell, 2007b). High evaporation peaks occurring more frequently in the case of the T3 treatment caused higher ET compared to T4 (Myburgh, 1998). Over the period that the irrigation treatments were applied, i.e. from August until April, the higher irrigation frequency (T3) resulted in $c a$. $8 \%$ higher ET than the lower frequency (T4). In the case of daily drip irrigation, timing and duration of the irrigation did not have a consistent effect on ET. Drip applications during the warmest part of the day (T2) increased ET by $c a$. $6 \%$ compared to early morning drip (T1).

The $\mathrm{k}_{\mathrm{c}}$ for the drip irrigated grapevines increased until the leaf canopy attained full cover in December (Table 11). Until April, drip $\mathrm{k}_{\mathrm{c}}$ values remained almost constant, followed by a decline when leaf shed began. This trend suggested that $\mathrm{k}_{\mathrm{c}}$ was primarily a function of the canopy, since limited evaporation occurred from the small wetted soil surface area. In the case of micro-sprinkler irrigation, $\mathrm{k}$ initially increased rapidly and reached a maximum between December and February. The micro-sprinkler $\mathrm{k}_{\mathrm{c}}$ values began to decline from March. The annual $\mathrm{k}_{\mathrm{c}}$ trend suggested that full surface evaporation losses driven by atmospheric conditions made a bigger contribution to ET in comparison to drip irrigation. The annual $\mathrm{k}_{\mathrm{c}}$ trend was similar to values reported previously for micro-sprinkler irrigated grapevines on horizontally orientated trellis systems in sandy soils (Myburgh, 2003b; Myburgh \& Howell, 2007b). The microsprinkler $\mathrm{k}_{\mathrm{c}}$ values were comparable to those determined for Thompson Seedless grapevines grown for dried grape production in a sandy soil near Upington in the same region (Myburgh, 2003b). However, the corresponding $\mathrm{k}_{\mathrm{c}}$ values occurred a month earlier at Augrabies than at Upington. This difference was probably caused by more rapid grapevine development under the warmer atmospheric conditions near Augrabies compared to Upington. Thompson Seedless grapes generally ripen during December near Augrabies compared to January near Upington. The different $\mathrm{k}_{\mathrm{c}}$ trends within one grape growing region suggested that it would probably be more realistic to consider $\mathrm{k}_{\mathrm{c}}$ also in terms of physiological phases than strictly on a monthly basis.

\section{CONCLUSIONS}

Under the given conditions, drip irrigation must be applied daily to maintain the high levels of water availability required for table grape production. In the case of micro-sprinklers, weekly irrigation intervals were too long, but twice a week was sufficient. Daily drip irrigation produced less grapes, but of the same quality as micro-sprinkler irrigation. Drip irrigation required less water, thereby contributing to more efficient irrigation water use. Micro-sprinkler irrigation promoted more weed growth in summer than drip irrigation. Although drainage could not be determined accurately, the $\mathrm{k}_{\mathrm{c}}$ values determined in this study could be useful for estimations of daily ET of drip and micro-sprinkler irrigation, respectively. The RAW of this soil was higher than expected, but $\Psi_{\mathrm{m}}$ should not drop below $-0.02 \mathrm{MPa}$, irrespective of the irrigation system used. Therefore, monitoring $\Psi_{\mathrm{m}}$ using tensiometers will be useful to ensure optimum soil water status between irrigations. The $\Psi_{\mathrm{m}}$ should be verified by using pressure chambers for measuring $\Psi_{\mathrm{PD}}$ or midday $\Psi_{\mathrm{L}}$ to assess grapevine water status. Since micro-sprinkler irrigation invariably produced higher yields than drip irrigation over the four seasons, it should be the preferred system for irrigation of table grapes under the given atmospheric and soil conditions. However, considering the larger irrigation volumes and possible negative effects on grape quality, micro-sprinkler irrigation might be less profitable than drip irrigation. If water resources are limited, or if high water cost reduces table grape profitability, drip irrigation would be a viable alternative. Under the given conditions, daily drip irrigation will be required during the growing season to maintain acceptable yields and grape quality.

\section{LITERATURE CITED}

Allen, R.G., Pereira, L.S., Raes, D. \& Smith, M., 1998. Crop evapotranspiration: Guidelines for computing crop water requirements. Irrig. Drain. Pap. 56, FAO, Rome.

Avenant, J.H., 1991. Trellising systems: Gable or Double slanting trellis. Farming in South Africa VORI 275/1991, ARC Infruitec-Nietvoorbij, Private Bag X5026, Stellenbosch 7599, South Africa.

Bravdo, B., 2000. Effect of mineral nutrition and salinity on grape production and wine quality. Acta Hort. 512, 23-30.

Bravdo, B., 2008. Nutrient management in table and wine grapes by fertigation. Acta Hort. 785, 165-174.

Conradie, W.J., 1994. Vineyard fertilisation. Proceedings of workshop on vineyard fertilization. Nietvoorbij, 30 September 1994. ARC InfruitecNietvoorbij, Private Bag X5026, 7599 Stellenbosch, South Africa.

Conradie, W.J. \& Myburgh, P.A., 2000. Fertigation of Vitis vinifera L. cv. Bukettraube/110 Richter on a sandy soil. S. Afr. J. Enol. Vitic. 21, 40-47. 
Deloire, A., Carbonneau, A., Wang, Z. \& Ojeda, H., 2004. Vine and water: A short review. J. Int. Sci. Vigne Vin 38, 1-13.

El-Ansary, D.O., Nakayama, S., Hirano, K. \& Okamoto, G., 2005. Response of Muscat Alexandria table grapes to post-veraison regulated deficit irrigation in Japan. Vitis 35, 45-46.

Fey, M., 2010. Soils of South Africa. Cambridge University Press, Cambridge.

Fourie, A., 1989. The effect of four soil water regimes on the performance of Barlinka table grapes in the Hex River Valley. Thesis, Stellenbosch University, Private Bag X1, 7602 Matieland, South Africa.

Fourie, J.C., 2005. Cover crop management in the vineyards of the Lower Orange River region, South Africa: 1. Performance of grass and broadleaf species. S. Afr. J. Enol. Vitic. 26, 140-146.

Greenspan, M., 2005. Integrated irrigation of California winegrapes. Prac. Vineyard \& Winery March/April 2005, 21-79.

Le Roux, E.G., 1974. A climate classification for the South Western Cape viticultural areas (in Afrikaans). Thesis, Stellenbosch University, Private Bag X1, 7602 Matieland (Stellenbosch), South Africa.

Ley, T.W., 1994. Irrigation system evaluation and improvement. In: Williams, K.M. \& Ley, T.W. (eds). Tree fruit irrigation: A comprehensive manual of deciduous tree fruit irrigation needs. Good Fruit Grower, Yakima, Washington. pp. 203-221.

McCullagh, P. \& Nelder, J.A., 1989. Generalized linear models. 2nd edition. Chapman Hall, New York.

Myburgh, P.A., 1996. Response of Vitis vinifera L. cv. Barlinka/Ramsey to soil water depletion levels with particular reference to trunk growth parameters. S. Afr. J. Enol. Vitic. 17, 3-14.

Myburgh, P.A., 1998. Water consumption of South African vineyards: A modelling approach based on the quantified combined effects of selected viticultural, soil and meteorological parameters. Thesis, University of Stellenbosch, Private Bag X1, Matieland 7602, South Africa.

Myburgh, P.A., 2003a. Possible flood irrigation technologies to reduce water use of Sultanina grapevines in a hot, arid climate. S. Afr. J. Plant Soil 20, 1-8.

Myburgh, P.A., 2003b. Responses of Vitis vinifera L. cv. Sultanina to level of soil water depletion under semi-arid conditions. S. Afr. J. Enol. Vitic. $24,16-24$.

Myburgh, P.A., 2003c. Responses of Vitis vinifera L. cv. Sultanina to water deficits during various pre and post harvest phases under semi-arid conditions. S. Afr. J. Enol. Vitic. 24, 25-33.

Myburgh, P.A., 2007a. An investigation into possible water savings with sub-surface irrigation (Part I) - Irrigation quantities, wetting patterns and root distribution. Wynboer Technical Yearbook 2007/08, 33-37.

Myburgh, P.A., 2007b. An investigation into possible water savings with sub-surface irrigation (Part II) - Plant water stress, growth, yield and quality. Wynboer Technical Yearbook 2007/08, 38-42.

Myburgh, P.A., 2008. The contribution of atmospheric humidity in winter to yield fluctuations of Sultanina in the Lower Orange River region. Wynboer Technical Yearbook 2008/09, 38-41.
Myburgh, P.A., 2010. Practical guidelines for the measurement of water potential in grapevine leaves. Wynboer Technical Yearbook 2010, 11-13.

Myburgh, P.A., 2011. Effect of different drip irrigation strategies on vineyards in sandy soil in the Lower Olifants River region (Part 1): Irrigation and soil water status. Wynboer Technical Yearbook 2011, 24-27.

Myburgh, P.A. \& Howell, C.L., 2006a. Water relations of Vitis vinifera L. $c v$. Sunred Seedless in response to soil water depletion before harvest. S. Afr. J. Enol. Vitic. 27, 196-201.

Myburgh, P.A. \& Howell, C.L., 2006b. Responses of Sunred Seedless and Muscat Supreme to irrigation during berry ripening. I - Growth, yield and juice analyses. S. Afr. Fr. J. Dec 06/Jan 07, 48-53.

Myburgh, P.A. \& Howell, C.L., 2007a. Responses of Sunred Seedless and Muscat Supreme to irrigation during berry ripening. II - Quality aspects. S. Afr. Fr. J. Feb 07/March 07, 28-32.

Myburgh, P.A. \& Howell, C.L., 2007b. Evapotranspiration of Vitis vinifera L. $c v s$ Sunred Seedless and Muscat Supreme in response to soil water depletion and irrigation cutoff during berry ripening. S. Afr. J. Plant Soil 24, 209-213.

Myburgh, P.A. \& Van der Walt, L.D., 2005. Cane water content and yield responses of Vitis vinifera L. cv. Sultanina to overhead irrigation during the dormant period. S. Afr. J. Enol. Vitic. 26, 1-5

Pérez-Harvey, J., 2008. Nutrition and irrigation related problems in table grapes. Acta Hort. 785, 175-182.

Saayman, D. \& Lambrechts, J.J.N., 1995. The effect of irrigation system and crop load on the vigour of Barlinka table grapes on a sandy soil, Hex River Valley. S. Afr. J. Enol. Vitic. 16, 26-34

Sadras, V.O., 2009. Does partial root-zone drying improve irrigation water productivity in the field? A meta-analysis. Irrig. Sci. 27, 183-190.

SAS, 1999. SAS/STAT User's Guide, Version 8, 1st printing, Volume 2. SAS Institute Inc, SAS Campus Drive, Cary, North Carolina 27513.

Scholander, P.F., Hammel, H.T., Bradstreet, E.D. \& Hemmingsen, E.A., 1965. Sap flow in vascular plants. Science 148, 339-346.

Shapiro, S.S. \& Wilk, M.B., 1965. An analysis of Variance Test for Normality (complete samples), Biometrika 52:591-611.

Van Rooyen, F.C., Weber, H.W. \& Levin, I., 1980. The response of grapes to a manipulation of the soil-plant-atmosphere continuum. I. Growth, yield and quality responses. Agrochemophysica 12, 59-68.

Van Zyl, J.L., 1984. Interrelationships among soil water regime, irrigation and water stress in the grapevine (Vitis vinifera L). Dissertation, Stellenbosch University, Private Bag X1, Matieland 7602, South Africa.

Volschenk, T., Fey, M.V. \& Zietsman, H.L., 2005. Situation analysis of problems for water quality management in the Lower Orange River region with special reference to the contribution of the foothills to salinization. WRC Report No: 1358/1/05. Water Research Commission, Private Bag X0031, Gezina, South Africa.

Winkler, A.J., 1962. General viticulture. University of California Press, Los Angeles. 